\title{
1-Methylcyclopropene Prevents Bud, Flower, and Leaf Abscission of Geraldton Waxflower
}

\author{
Margrethe Serek ${ }^{1}$ \\ The Royal Veterinary and Agricultural University, Department of Agricultural \\ Sciences, Section of Horticulture, Rolighedsvej 23, 1958 Frederiksberg C., \\ Denmark
}

\author{
Edward C. Sisler ${ }^{2}$ \\ North Carolina State University, Department of Biochemistry, Raleigh, \\ NC 27695
}

\section{Tsipora Tirosh ${ }^{3}$ and Shimon Mayak ${ }^{2}$}

The Hebrew University of Jerusalem, The Kennedy-Leigh Center for Horticulture Research, Faculty of Agriculture, P.O. Box 12, Rehovot 76-100, Israel

Additional index words. dry storage, ethylene, 1-MCP, postharvest

Geraldton waxflower (Chamelaucium uncinatum Schauer) is one of the major cut flowers in Israel, and is exported to many European countries (Israel Flower Marketing Board-Agrexco, 1994). However, longdistance transport, usually in darkness and without water, with possible exposure to exogenous ethylene during distribution, causes extensive abscission of floral organs (Joyce, 1988, 1989, 1993). Exposure of the sprigs to ethylene causes bud and flower abscission, and the most successful preventive treatment to date is pulsing with the anionic silver thiosulfate complex (STS), an inhibitor of ethylene action (Joyce, 1988, 1989). Recently, a new, nontoxic inhibitor of ethylene action, 1methylcyclopropene (1-MCP), has been introduced (Serek et al., 1994, 1995; Sisler et al., 1995). This compound appears to act as a competitive and apparently irreversible inhibitor of ethylene binding (Sisler et al., 1995). Treatment with 1-MCP at very low concentrations effectively eliminates the effects of ethylene on ethylene-sensitive potted plants and cut flowers (Serek et al., 1994, 1995; Sisler et al., 1995).

The purpose of these experiments was to evaluate the effectiveness of 1-MCP in preventing abscission of plant organs from flowering branches of Geraldton waxflower.

Received for publication 10 Jan. 1995. Accepted for publication 7 June 1995. The experiments were supported by a grant from the Danish Ministry of Agriculture (grant no. NON93-KVL-15) (M.S.) and the chief scientist of the Ministry of Agriculture, Israel (T.T. and S.M.).The cost of publishing this paper was defrayed in part by the payment of page charges. Under postal regulations, this paper therefore must be hereby marked advertisement solely to indicate this fact.

${ }^{1}$ Associate Professor; to whom reprint requests should be addressed.

${ }^{2}$ Professor.

${ }^{3}$ Technician.
Plant material. Cut flowering branches of Geraldton waxflower ('Wendy'), with $30 \%$ of their flower buds fully opened, were obtained from a local nursery and transferred to our laboratory at the Faculty of Agriculture in Rehovot, Israel. From harvest until initiation of the experiments, the flowers were maintained in deionized water at $21 \mathrm{C}$.

1-MCP and ethylene treatments. Geraldton waxflower sprigs were held in deionized (DI) water and placed in 130-liter Plexiglass chambers illuminated by cool-white fluorescent lamps (Tadiran, Israel) at an irradiance of 14 $\mu \mathrm{mol} \cdot \mathrm{m}^{-2} \cdot \mathrm{s}^{-1}$, at $21 \mathrm{C}$, and ethylene $\left(2 \mu \mathrm{l} \cdot\right.$ liter $\left.^{-1}\right)$ and 1-MCP (200 nl.liter $\left.{ }^{-1}\right)$ were injected into the chambers. Treatments were as follows: 1 ) $13 \mathrm{~h} \mathrm{1-MCP}$ then $6 \mathrm{~h}$ air; 2) simultaneous $13 \mathrm{~h}$ 1-MCP and ethylene then $6 \mathrm{~h}$ air; 3) $6 \mathrm{~h} 1-\mathrm{MCP}$ then simultaneous $13 \mathrm{~h} 1-\mathrm{MCP}$ and ethylene; 4) $13 \mathrm{~h}$ ethylene then $6 \mathrm{~h}$ air; 5) $19 \mathrm{~h}$ air (control). At the end of the treatments, the sprigs were removed and placed under the light and temperature conditions noted, including $50 \%$ to $60 \%$ relative humidity $(\mathrm{RH})$. The sprigs were arranged in a randomized complete-block design, with six replications per block. Bud and flower abscission were recorded 1 day after termination of the treatments.

Dry storage. 1-MCP-treated (200 nl.liter ${ }^{-1}$ for $6 \mathrm{~h}$ ) or nontreated (control) sprigs were packed dry in paper bags (six replications per block), and held for $72 \mathrm{~h}$ at $21 \mathrm{C}$ and $50 \%$ to $60 \% \mathrm{RH}$ in darkness. Following storage, the stems of the sprigs were recut, placed in DI water under light at $14 \mu \mathrm{mol} \cdot \mathrm{m}^{-2} \cdot \mathrm{s}^{-1}, 21 \mathrm{C}$, and $50 \%$ to $60 \%$ RH. Following $48 \mathrm{~h}$ of dry storage, cumulative bud or flower and leaf abscission were recorded.

1-MCP reduced bud and flower abscission in response to ethylene when 1-MCP and ethylene were applied simultaneously and was even more effective when 1-MCP was applied $6 \mathrm{~h}$ before ethylene treatment (Table 1). No buds or flowers dropped or senesced from 1-
MCP-treated or nontreated (control) sprigs kept in air.

Bud, flower, and leaf abscission from drystored Geraldton waxflower sprigs treated with 1 -MCP was reduced by 36,47 , and 28 percentage points, respectively, as compared to the controls (Table 2).

Extensive dehydration may occur during shipment and storage of flowers. Dehydration may elevate ethylene production, leading to abscission of leaves, buds, and flowers. Joyce (1993) reported that bud and flower abscission in waxflower sprigs, induced by water deficit, were reduced by pretreatment with STS. This observation suggests involvement of ethylene in abscission during postharvest handling. In our experiment, 1-MCP, an alternative to STS, strongly reduced bud, flower, and leaf abscission caused by stresses associated with dry storage.

The dramatic inhibition of the effects of ethylene in Geraldton waxflowers by 1-MCP treatment suggests that the use of this simple, nontoxic, organic compound will be a viable replacement for the currently commercially used STS complex.

\section{Literature Cited}

Israel Flower Marketing Board-Agrexco. 1994. Agrexco Ann. Rpt. (in Hebrew).

Joyce, D.C. 1988. Postharvest characteristics of Geraldton wax flowers. J. Amer. Soc. Hort. Sci. 13:738-742.

Joyce, D.C. 1989. Treatments to prevent flower abscission in Geraldton wax. HortScience 24:391.

Joyce, D.C. 1993. Postharvest floral organ fall in Geraldton waxflower (Chamelaucium uncinatum Schauer). Austral. J. Expt. Agr. 33:481-487.

Serek, M., E.C. Sisler, and M.S. Reid. 1994. Novel gaseous inhibitor of ethylene binding prevents ethylene effects in potted flowering plants. J. Amer. Soc. Hort. Sci. 119:1230-1233.

Serek, M., E.C. Sisler, and M.S. Reid. 1995. Effects of $1-\mathrm{MCP}$ on the vase life and ethylene response of cut flowers. Plant Growth Regulat. 16:93-97.

Sisler, E.C., E. Dupille, and M. Serek. 1995. Effect of 1methylcyclopropene and methylenecyclopropane on ethylene binding and ethylene action on cut carnations. Plant Growth Regulat. (In press.)

Table 1. Effect of ethylene and 1-MCP on bud or flower abscission (\%) from freshly harvested Geraldton waxflower.

\begin{tabular}{lrr}
\hline & \multicolumn{2}{c}{ Abscission (\%) } \\
\cline { 2 - 3 } Treatments & \multicolumn{1}{c}{ Bud } & Flower \\
\hline Control & $0 \mathrm{a}^{\mathrm{z}}$ & $0 \mathrm{a}$ \\
1-MCP & $0 \mathrm{a}$ & $0 \mathrm{a}$ \\
Ethylene & $56 \mathrm{c}$ & $40 \mathrm{~b}$ \\
1-MCP + ethylene, & & \\
simultaneously & $14 \mathrm{~b}$ & $8 \mathrm{a}$ \\
1-MCP then ethylene & $0 \mathrm{a}$ & $1 \mathrm{a}$ \\
\hline zMean & separation in
\end{tabular}

${ }^{\mathrm{z}}$ Mean separation in columns at $P \leq 0.05$ by $t$ test probability values for the hypotheses $\mathrm{H}_{\mathrm{O}}$ : LSM(i) = $\operatorname{LSM}(\mathrm{j})$.

Table 2. Bud, flower, and leaf abscission from drystored Geraldton waxflower sprigs following treatment with 1-MCP.

\begin{tabular}{llcl}
\hline & \multicolumn{3}{c}{ Abscission (\%) } \\
\cline { 2 - 4 } $1-\mathrm{BCP}$ & Bud & Flower & Leaf \\
\hline- & $55 \mathrm{a}^{\mathrm{z}}$ & $57 \mathrm{a}$ & $49 \mathrm{a}$ \\
+ & $19 \mathrm{~b}$ & $10 \mathrm{~b}$ & $21 \mathrm{~b}$ \\
\hline
\end{tabular}

${ }^{\mathrm{z}}$ Mean separation in columns are statistically different at $P \leq 0.01$ by orthogonal comparisons. 